\title{
Origins of maize: a further paradox resolved
}

\author{
Ruairidh J. H. Sawers* and Nidia L. Sanchez Leon \\ Laboratorio Nacional de Genómica para la Biodiversidad, Centro de Investigación y Estudios Avanzados, Irapuato, México \\ ${ }^{*}$ Correspondence: rsawers@langebio.cinvestav.mx
}

\section{A commentary on}

Genetic signals of origin, spread, and introgression in a large sample of maize landraces

by van Heerwaarden, J., Doebley, J., Briggs, W. H., Glaubitz, J. C., Goodman, M. M., de Jesus Sanchez Gonzalez, J., and Ross-Ibarra, J. (2011). Proc. Natl. Acad. Sci. U.S.A. 108, 1088-1092.

For over a century, the enigmatic history of maize (Zea mays ssp. mays) has fascinated and frustrated botanists and archeologists alike. The cultures and civilizations of pre-Hispanic Mesoamerica stand as a lasting testament to the importance of maize as a driving force for socio-economic development. Yet, the full story of maize domestication and subsequent radiation remains unresolved. In recent years, an increase in the availability of genetic data has greatly advanced our understanding of maize history. In their article of January 2011, van Heerwaarden et al. (2011) report the most comprehensive molecular survey yet of $Z$. mays ssp., and shed further light on one of the remaining paradoxes of maize domestication.

Perhaps of all that has proved obscure in the riddle of maize domestication, nothing is as paradoxical as the plant itself: the geneticist Paul Mangelsdorf contended that if maize had been derived from any known species it would represent "the wildest departure of a cultivated plant from its wild ancestor which still comes within man's purview" (see Galinat, 1971). Nonetheless, his subsequent search for an unknown wild-maize progenitor was to prove fruitless. Current consensus is that maize was indeed domesticated from an extant grass, and one that is still abundant in Mexico today: Balsas teosinte (Matsuoka et al., 2002). This plant is now known as $Z$. mays ssp. parviglumis to reflect its close affinity with cultivated maize.

While the parviglumis ancestry of maize is unambiguous, one aspect of the story appears to be inconsistent. Of all the maize varieties surveyed, it is consistently the highland landraces that show the greatest genetic similarity to parviglumis. The reasonable interpretation of such data is that the highland landraces are ancestors to all other maize groups, and that the highlands themselves are the center of domestication. Parviglumis, however, is endemic to lowland regions (Figure 1). How, then, could cultivated maize have been domesticated in the highlands if there was no parviglumis there? Or, if domestication occurred in the highlands, how could parviglumis be the direct ancestor of maize?

Two hypotheses have been advanced to reconcile parviglumis ancestry with the apparently primitive position of the highland maize group (see van Heerwaarden et al., 2011). First, 9,000 years ago, parviglumis might indeed have been growing in the highlands and domestication followed from such highland populations. This, however, is unlikely given the cooler, drier climate at the time. Alternatively, maize might have originated from lowland parviglumis and spread to the highlands, only to radiate back to replace the earliest domesticated populations in the lowlands. This second hypothesis seems unlikely also, requiring as it does that highland maize returning to the lowlands would outcompete existing, presumably well adapted populations: to be even plausible, such a scenario might require the action of strong cultural selection imposed by early farming communities.

van Heerwaarden et al. (2011) have apparently resolved this paradox by providing a third hypothesis. The authors report evidence for large-scale gene-flow from a second teosinte, $Z$. mays ssp. mexicana, to highland maize populations: teosintes and cultivated maize have the same number of chromosomes and are interfertile, such that there is no biological barrier to such gene-flow. Unlike parviglumis, mexicana is common in the highlands and there is ample opportunity for hybridization. Through analysis of a large data-set of maize and teosinte DNA polymorphisms, van Heerwaarden et al. (2011) provide evidence of approximately $20 \%$ introgression of mexicana to maize varieties growing at over $1500 \mathrm{~m}$. Below this altitude, only 1\% such introgression is observed.

Given the phylogenetic proximity of mexicana to parviglumis, these altitudespecific differences in admixture are more than sufficient to explain the close affinity of highland maize to teosinte; i.e., highland maize populations show genetic similarity to parviglumis because of mexicana genes acquired after domestication. On the basis of their findings, van Heerwaarden et al. (2011) reconstruct a maize phylogeny excluding both mexicana and parviglumis. In place, the authors infer ancestral states with respect to extant maize populations and calculate drift accordingly. By this analysis, they identify varieties from Western Mexico as ancestral, and the highland varieties as a divergent group. As such, the authors place the center of maize domestication within the geographic range of the parviglumis ancestor.

Molecular characterization of the highland landraces has not been the only difficulty to reconcile with a center of domestication in Balsas. Long before the availability of large-scale genetic datasets, the highland landraces were already thought to be primitive on the basis of morphological characterization (Wellhausen et al., 1952). Furthermore, much of the iconic archeological work of Richard MacNeish was carried out in the highland caves of Tehuacán, Mexico (Hastorf, 2009). Although MacNeish's pragmatic choice of field sites was based on the expectation that material would be better preserved in such localities, it no doubt served to promote the idea that ancient groups would be found in the highlands. In recent years, however, archeologists, prompted by the molecular data, have turned their attention to the Balsas region. Subsequent phytolith and cultural finds, while less spectacular than 


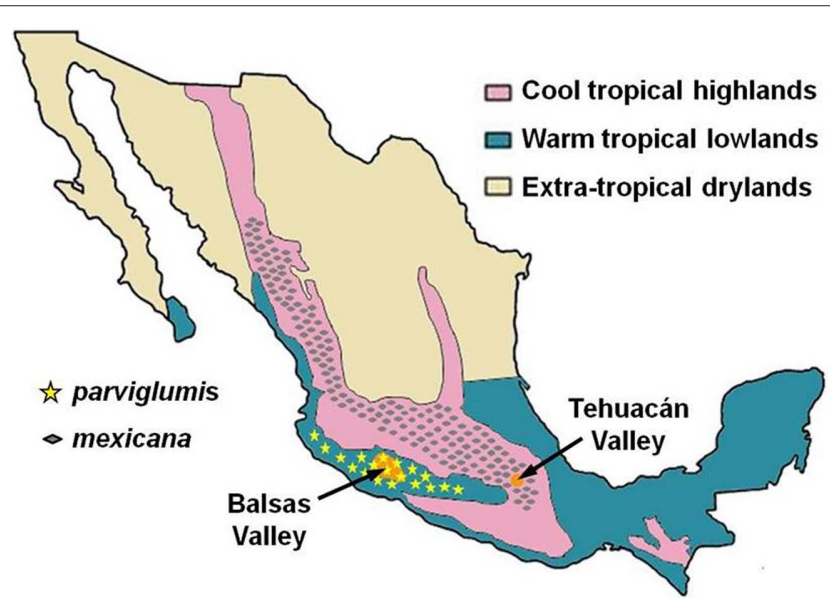

FIGURE 1 | Geographical distribution of parviglumis and mexicana teosintes. Map of Mexico showing major ecological zones. The Balsas and Tehuacán Valley regions also shown. Modified after McClung de Tapia (1992) and Matsuoka et al. (2002).

highland macrobotanical specimens, have been dated to almost 9,000 years ago, consistent with a Balsas origin for cultivated maize (Piperno et al., 2009).

Admixture on the scale reported by van Heerwaarden et al. (2011) may be driven, at least in part, by adaptive advantage. Clearly, this would fit well with a scenario in which the spread of lowland maize from the point of domestication to highland environments was aided by introgression of favorable alleles from endemic mexicana populations. Molecular studies have consistently placed highland landraces apart from other maize groups (Reif et al., 2006; Warburton et al., 2008). Irrespective of whether considered primitive or divergent, the highland maize group remains an important potential source of genetic novelty. Significantly, the group as a whole has so far contributed relatively little to modern non-temperate maize breeding pools (Warburton et al., 2008). With the recent sequencing of the gene-space of the landrace Palomero Toluqueño (Vielle-Calzada et al., 2009) - a highland popcorn estimated to have $12 \%$ mexicana ancestry (Matsuoka et al., 2002), and ongoing analyses of maize germplasm (e.g., the Iowa State GEM project; the SAGARPA/CIMMYT MasAgro initiative), the exciting potential exists to further understand and utilize this novel genetic variation.

\section{ACKNOWLEDGMENT}

We thank Jeffrey Ross-Ibarra for his helpful comments.

Galinat, W. C. (1971). The origin of maize. Annu. Rev. Genet. 5, 447-478.

Hastorf, C. A. (2009). Rio Balsas most likely region for maize domestication. Proc. Natl. Acad. Sci. U.S.A. 106, 4957-4958.

Matsuoka, Y., Vigouroux, Y., Goodman, M. M., Sanchez, G. J., Buckler, E., and Doebley, J. (2002). A single domestication for maize shown by multilocus micro-

\section{REFERENCES}

satellite genotyping. Proc. Natl. Acad. Sci. U.S.A. 99, 6080-6084.

McClung de Tapia, E. (1992). "The origins of agriculture in mesoamerica and central America," in The Origins of Agriculture, an International Perspective, eds C. W. Cowan and P. J. Watson (Washington, DC: Smithsonian Institution Press), 143-172.

Piperno, D. R., Ranere, A. J., Holst, I., Iriarte, J., and Dickau, R. (2009). Starch grain and phytolith evidence for early ninth millennium B.P. maize from the Central Balsas River Valley, Mexico. Proc. Natl. Acad. Sci. U.S.A. 106, 5019-5024.

Reif, J. C., Warburton, M. L., Xia, X. C., Hoisington, D. A., Crossa, J., Taba, S., Muminović, J., Bohn, M., Frisch M., and Melchinger, A. E. (2006). Grouping of accessions of Mexican races of maize revisited with SSR markers. Theor. Appl. Genet. 113, 177-185.

van Heerwaarden, J., Doebley, J., Briggs, W. H., Glaubitz, J. C., Goodman, M. M., de Jesus Sanchez Gonzalez, J., and Ross-Ibarra, J. (2011). Genetic signals of origin, spread, and introgression in a large sample of maize landraces. Proc. Natl. Acad. Sci. U.S.A. 108, 1088-1092.

Vielle-Calzada, J. P., Martínez de la Vega, O., HernándezGuzmán, G., Ibarra-Laclette, E., Alvarez-Mejía, C., Vega-Arreguín, J. C., Jiménez-Moraila, B., FernándezCortés, A., Corona-Armenta, G., Herrera-Estrella, L., and Herrera-Estrella, A. (2009). The palomero genome suggests metal effects on domestication. Science 326, 1078.

Warburton, M. L., Reif, J. C., Frisch, M., Bohn, M., Bedoya, C., Xia, X. C., Crossa, J., Franco, J., Hoisington, D., Pixley, K., Taba, S., and Melchinger, A. E. (2008). Genetic diversity in CIMMYT nontemperate maize germplasm: landraces, open pollinated varieties, and inbred lines. Crop Sci. 48, 617-624.

Wellhausen, E. J., Roberts, L. M.,Hernandez, Eand in collaboration with Mangelsdorf, P. C. (1952). Races of Maize in Mexico. Cambridge, MA: Harvard University Press.

Received: 17 June 2011; accepted:07 August 2011; published online: 23 August 2011.

Citation: Sawers RJH and Sanchez Leon NL (2011) Origins of maize: a further paradox resolved. Front. Gene. 2:53. doi: 10.3389/fgene.2011.00053

This article was submitted to Frontiers in Plant Genetics and Genomics, a specialty of Frontiers in Genetics.

Copyright (c) 2011 Sawers and Sanchez Leon. This is an open-access article subject to a non-exclusive license between the authors and Frontiers Media SA, which permits use, distribution and reproduction in other forums, provided the original authors and source are credited and other Frontiers conditions are complied with. 